Article

\title{
Religious Festival Marketing: Distinguishing between Devout Believers and Tourists
}

\author{
Kuo-Yan Wang ${ }^{1}{ }^{\mathbb{D}}$, Azilah Kasim ${ }^{2, *}$ and Jing Yu ${ }^{1}$ \\ 1 Department of Marketing in School of Economics and Management, Guangdong University of Petrochemical \\ Technology, Maoming 525000, China; kywang@gdupt.edu.cn (K.-Y.W.); yujing@gdupt.edu.cn (J.Y.) \\ 2 School of Tourism, Hospitality \& Event Management, Universiti Utara Malaysia, Sintok 06010, Malaysia \\ * Correspondence: azilah@uum.edu.my
}

Received: 2 July 2020; Accepted: 10 August 2020; Published: 12 August 2020

check for updates

\begin{abstract}
Customer classification is an integral part of marketing planning activities. Researchers have struggled to classify "pilgrims" and "tourists" because these groups overlap to a large extent in terms of their identities while participating in religious activities/sightseeing. To achieve sustainable tourism development for the region with rich religious and cultural characteristics, the present article outlines a process for analyzing the motivation of participants attending religious festival of Mazu in Taiwan and then classifies religious festival participants according to their motivations. Using cluster sampling, a total of 280 responses were obtained and analyzed. The results revealed four different motivation categories: Fun traveler, devout believer, cultural enthusiast, and religious pragmatist. The study concludes that while festivalgoers are influenced by secularization to some extent, the original doctrine of the religion epitomized in the festivals fundamentally retains the essence and spirit of its religious rituals. The findings may have a significant value for the development of religious tourism marketing as it offers a foundation for future research seeking to develop regional cultural and religious sightseeing attractions sustainably.
\end{abstract}

Keywords: festival; customer classification; factor analysis; motivation; folklore belief

\section{Introduction}

To stimulate sustainable brand development, firms usually exert great efforts to classify their customers, allowing them to identify the most profitable target markets and optimally target greater numbers of such customers. Customer classification involves the subdivision of a market into discrete customer groups that share similar characteristics, which can be a powerful means of identifying unmet customer needs (Onwezen 2018). Companies that identify underserved segments can subsequently outperform the competition by developing unique products and services. Generally, customer classification can help a business develop marketing campaigns and pricing strategies to extract maximum value from both high- and low-profit customers (Bhatnagar and Gopalaswamy 2017). A company, as well as an ad-hoc organization, can use customer classification as the principal basis for allocating resources to product development, marketing, service, and delivery programs (Timoshenko and Hauser 2019; Wang et al. 2018).

Organizations increasingly use festivals as a means to promote tourism and stimulate the regional economy due to the added value that festivals offer: The potential to reinforce local economies, encourage the conservation of festival-themed commodities, sustain and preserve local identities, and create opportunities for tourists to engage with local cultures and people (Viljoen et al. 2017; Berg and Sevón 2014; Saayman and Saayman 2006). For festival-related organizations, therefore, an accurate customer classification can help marketers better target customers during the planning phases, thus attracting more sponsors and income. 
Festivals are a type of cultural event, highlighting the unique features of a destination or theme (Zhang et al. 2019). The explosion in festival numbers has multifaceted causes. Supply factors have an influence, including cultural-based event planning, tourism industry development, and civic movement repositioning (Bakas et al. 2019; Duxbury et al. 2019). Demand factors also play a role, including serious leisure, lifestyle sampling, socialization needs, and the desire for creative and firsthand experiences (Lyu and Lee 2016). Festivals can have many themes, such as music (Li and Wood 2016; Rowley and Williams 2008), sightseeing attractions (Getz and Page 2016; Getz 2010; Lee et al. 2004), and sport competitions (Brown et al. 2016; Brown 2007). Previous research has discussed, in-depth, visitors' motivations for attending festivals and special events (Ruiz et al. 2019; Grappi and Montanari 2011; Kim et al. 2006; Prentice and Andersen 2003; Dewar et al. 2001; Crompton and McKay 1997). However, few studies specifically address religious festivals, as it is difficult to determine participants' motivations for attending such events. Thus, the application of appropriate strategies for festival marketing programs is a challenge for activity sponsors, festival organizers, and tourism sector planners. In these cases, the visitor is viewed as being just along for the ride in a defocused carnival environment.

The phrase matsuri in the Japanese language denotes "serving" and "entertaining" the deity in Japanese religion (Kitagawa 1988). The appearance or presentation of matsuri, a ritual or ceremony that serves as the embodiment of meaning, effectively establishes morality, and religious festivals around the globe can last for long periods. In Kawano's (2005) definition of ritual practice, rituals are traditionally presented to ordinary people seeking to gain something from their voluntary participation. In practical terms, religious rituals themselves constitute a central force of community cohesion as they can attract wide community attention and participation. One such ritual is the annual festivals of the Hitachinokuni Sosha Shrine in Ishioka City, Ibaraki Prefecture, and Giōn Matsuri in Kyoto Prefecture, Japan (Kim 2005). Similarly, folkloric beliefs, rituals, and ceremonies in Chinese tradition express deity reverence and have been practiced for several hundred years in Taiwan. From the perspective of a social-functional interpretation, an efficient religious festival also helps regional religions and cultural developments. Shimazono (1998) asserted that the idea of the general acceptance of a religion stems from religious organizations and their followers, who claim that participation in religious activities is voluntary. Participants tend to follow, to a certain extent, suggestions regarding what constitutes a suitable donation. Nevertheless, the promotional efforts of religious organizations, such as the sale of objects of worship, incense sticks, amulets, and deity-themed objects, are frequently visible. Since people widely believe that the purchase of these objects guarantees an end to misfortune, the danger of dishonest behavior in the pursuit of personal profit exists (Wang 2019; Wang 2014a). The marketing of religious commodities (e.g., religious objects, merchandise, or souvenirs) may also elicit similar attitudes where, while an underlying sacred meaning remains, there is no objection towards the commercialization of religious products (Zaidman 2003). The literature, however, does not specifically discuss this in the context of religious events such as religious cultural festivals or deity birthdate ceremonies. In addition, there is still very little discourse on the motivations of the participants of such an event. Therefore, this empirical study focuses on this gap of knowledge using a Chinese Taoist temple festival organizer in Taiwan as its research setting.

The rest of this paper is organized as follows. We briefly present the most influential Tao deity, Mazu, worshiped in Taiwan. This figure remains an indispensable part of Chinese cultural life because Taiwanese folkloric beliefs are heavily influenced by the Mainland Chinese provinces of Fujian and Guangdong, as exemplified by the ancestral homes built during the immigration wave of the 17th through the 19th centuries (Wang 2014a). For an improved customer classification of sustainable regional religious or culture-themed tourism development, the next section describes the importance of the motivation of participants in religious activities. In addition, the results of a factor analysis, in terms of basic statistics for participants' motivation in religious festivals, are presented. The final section concludes this empirical study. 


\section{Research Focuses}

\subsection{Mazu Belief Practices in Taiwan}

Diachronic folkloric beliefs in Chinese society and religious culture have developed over the past few thousand years and are a mixture of Buddhism, Confucianism, and Taoism. Belonging to the same cultural circle and tradition of philosophical thought, religions in Taiwan are syncretized and pantheistic (Wang 2014a; Chang 2009). In addition to the inherent aboriginal culture (Liao et al. 2019), Taiwanese folkloric beliefs are heavily influenced by Fujian and Guangdong, two provinces in Mainland China, because of the ancestral homes built during the immigration waves between the 17th and 19th centuries. As the immigrant population adjusted to a new living environment and an uncertain future, communal rituals, and folkloric beliefs derived from the mainland immigrants' original religions became widespread on the island (Wang 2014a). These festivals have shaped the belief system of contemporary ethnic Chinese residents now living in Taiwan. More than 10,000 Taoist, Buddhist, and Confucian religious sites exhibit the dominant Chinese pantheistic belief structure.

Folkloric beliefs are a form of religion that recognizes all deities as gods. Temples dedicated to the deities commonly form alliances with several temples of similar characteristics dedicated to the same deities. According to Chinese pantheistic beliefs, the deity represents the soul or spirit. This belief may derive from Taoist religious communal rituals. As the most influential goddess of the sea in China, Mazu is at the center of beliefs and customs, including rituals, ceremonies, and folk practices, throughout coastal areas, with millions of followers (Chang et al. 2012). Scholars have argued that the role of Mazu is more than that of a guardian angel for fishermen (Guo et al. 2006; Shuo et al. 2009). The Mazu belief, as a social cohesion catalyst in Chinese society, was inscribed on the representative list of the Intangible Cultural Heritage of Humanity, of the United Nations Educational, Scientific, and Culture Organization (UNESCO) in 2009 (UNESCO and The Mazu Belief and Customs 2009). Pilgrims gather in the so-called holy land for specific festivals, such as that held on March 23 of every lunar year, to celebrate the birthday of Mazu. Many related activities accompany this commemoration, such as group worship ceremonies and pilgrimages to locations where the temple is enshrined. Even during the period of Japanese colonial occupation, the rulers did not challenge the power of Mazu beliefs. The rulers of the Taiwan Colonial Government showed appreciation for Mazu's mercy, with the additional purpose of winning over different ethnic groups. Currently, for politicians-from island wide leaders to village headmen, regardless of their own beliefs_visiting and praying in famous temples represents a way to win the votes, hearts, and minds of the people. After years of development, Mazu now acts as a bridge for numerous politicians joining Mazu-themed festivals. From tourism point of view, Mazu celebrations are important tourism income earners as they could attract millions of visitors willing to spend nine days marching through different cities just to celebrate the deity's birthday (Wong 2013, April 12).

Pilgrimage enables tourism-related activities and is an important regional characteristic because it embodies the strong local folk culture. In the case of Dajia Mazu Pilgrimage, the festival involves a nine-day parade carrying Mazu statue in a chair for $12 \mathrm{~h}$ a day through mountains and rough terrains. The parade starts and ends at the Jenn Lann Temple in the city but will pass through more than 100 temples at the coastal counties of Changhua, Yunlin and Chiayi in its $300 \mathrm{~km}$ journey (Wong 2013, April 12). It is said that every temple stop provides interaction opportunities between Mazu Goddess with the Mazu statue that resides in that particular temple, that empowers the temple and brings luck to the local community. Approximately 200,000 pilgrims are involved in each Dajia Mazu Pilgrimage. They receive free food and sleep everywhere (the local community's gardens, garages, living rooms etc.) for free at each of the stops (Tsao 2014).

Though the festival was the result of public-private cooperation in Taichung city (Tsao 2014), the steady increase of participants has led to a booming growth of tourism, cultural activities, artistic activities as well as local food and transportation businesses throughout the event. In 2013, the total number of participants was five millions people (Wong 2013, April 12). This essentially highlights the 
tourism importance of the event which brings with it the issue of commodification of religious tourism, where mythical narration is combined with non-religious demands, providing tourism opportunities for areas surrounding pilgrimage sites (Bixby 2006). In recent years, many temples in Taiwan have strongly promoted folkloric beliefs in cultural development to fascinate believers and tourists, thereby increasing donations and marketing revenues, including the creative product development of religious items. Figure 1 displays deity-themed cultural creative goods (e.g., amulets, postcards, key rings, and USB drives) in vending machines at a historical temple in Southern Taiwan.

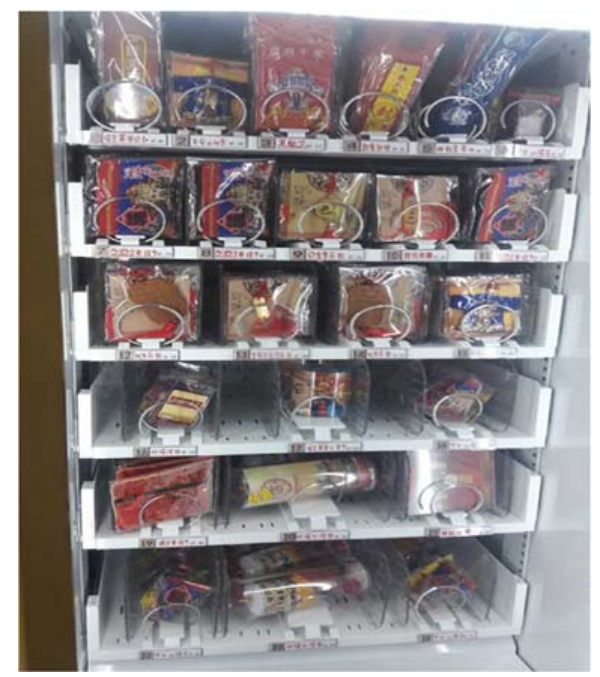

Figure 1. A vending machine with religious-themed creative goods in a Taiwanese temple (Photo from the author).

\subsection{Classifying Religious Festival Participants: Filling in the Blanks}

In general, non-profit organizations have more of a need for marketing than for-profit organizations because the former mainly derive their revenues from social sponsorships (Bowdin et al. 2006). In addition, a favorable public image facilitates capital mobility (Moore 2000). Chinese temples have a special classification that falls somewhere between for-profit and non-profit, as they mainly receive funding from worshiper contributions, with some subsidies from local authorities. A temple needs to allocate resources to gain social recognition and attract more loyal believers (customers) to survive in a fiercely competitive and highly overlapping environment (Iriobe and Abiola-Oke 2019; Collins-Kreiner 2018; Wang 2014b). In recent years, temples have begun to carry out an increasing number of regional religious and culture-based activities, which attract more visitors, lead to the development of the local tourism sector and peripheral industries and strengthen the temple's reputation (Wang 2014b). Therefore, optimizing services to attract believers/customers/donators has become a top priority (Wang 2014a). That being said, as Prentice and Andersen (2003) noted, "Not everyone at a destination during a festival can be assumed to be a festival-goer." It is difficult to correctly classify pilgrims and tourists. A further question is whether or not the commercial development of religious festivals has harmed the spirituality inherent in the associated religious rituals and belief structures.

Scholars have discussed the differences and similarities between tourists and pilgrims (Durán-Sánchez et al. 2018; Mwebaza et al. 2018; Chang et al. 2012). Both tourists and pilgrims require discretionary income, leisure time, and social sanctions permissive of travel (Durán-Sánchez et al. 2018). Secularization of religious communication and development is inevitable in the modern era (Kluver and Cheong 2007) thereby making it increasingly difficult to distinguish between pilgrims and tourists. Accordingly, facing the modern secularization, the behaviors, rituals, and motivations of religious festival participants may have been adjusted. Cohen (1992) for example, has argued that visitors to a pilgrimage site may actually not be followers of that site's religion and therefore should be classified as just ordinary travelers. 
The term pilgrimage itself comes to denote a leisure activity without a firm religious purpose (Liutikas 2017; Matoga and Pawłowska 2018). Pilgrimages have powerful political, economic, social, and cultural implications and can even affect global trade and social phenomena. Pilgrimage inevitably necessitates spatial movement, and such a form of "circulation" has no less an effect on the environment (Collins-Kreiner 2010; Kim et al. 2016; Moufahim and Lichrou 2019). Moreover, the concept of a "large-scale acquaintance network" distributed through the power of the Internet (Tomochi 2010; Tanaka 2014) is key. The acceleration of information exchange and social networks in small-scale societies occurs easily, and large-scale informal organizations cannot be ignored (Balbo et al. 2016) because many religious communities have utilized the Internet as part of their religious mission and growth strategy (Kluver and Cheong 2007).

The above-mentioned trend may have encouraged many people to focus attention on their own regional cultural and religious heritage preservation activities (Chen 2016). This trend could explain people's motivations to participate in religious festival activities and simultaneously highlight the importance of effective pilgrim/tourist classification. However, an in-depth discussion of actual, more complex phenomena related to distinguishing the real motivations behind a pilgrim or a tourist attending a religious activity is still lacking. Hence this study attempts to address the question-when a religious festival such as the Mazu festival becomes more commercial-driven, does it affect participants' motivations as well? The question of whether or not intensive marketing and promotion can affect 'religious purity' or the original reason for participating in a religious event (Shiomura 2009) is worth discussing. That is why this study aims to address the long-standing problem of distinguishing between pilgrims and tourists in religious festivals in attempt to provide a more comprehensive view of the issue and its implications for temple managers as organizers.

\section{Research Methods}

\subsection{Instruments}

The survey instrument was based on that used by Crompton and McKay (1997), which is considered to be an effective analysis measurement tool. This instrument, which is based on segmenting visitors and identifying their specific needs and behaviors, enables festival organizers to develop effective marketing strategies and, ultimately, ensure their long-term economic viability. Therefore, numerous studies on motivations within festival research have used this tool to investigate World Heritage Sites (Woosnam et al. 2018), food-themed events (Özdemir and Seyitoğlu 2017), sexual tourism (Ying and Wen 2019), special holidays (Mariani and Giorgio 2017), and so on.

The instrument starts with information on respondents, such as festival visit times, religious beliefs, and where respondents heard about the event, followed by the motive-related items for observing respondents' attitudes toward religious festival participation. The responses were analyzed to make an appropriate classification using factor analysis.

Numerous articles regarding marketing research have applied multivariate methods to problems of customer classification. Factor analysis techniques are among the many potentially useful methods for researchers (Takele 2019). Many academics have recognized factor analysis as a simple-to-use survey method with a great deal of practical value, particularly for market segmentation and customer classification research (Boivin and Tanguay 2019; Lee and Kwag 2019; Dhakal et al. 2017).

For this empirical study, we applied factor analysis techniques to classify participants of several Mazu temple festivals held in Taiwan, thereby demonstrating religious festival visitor typology in a realistic setting. The advantages of using quantitative research are that it is suitable for larger sample sizes, has high objectivity and accuracy, saves time in information collection and processing, and is more cost-effective. Hence, the results were obtained by the research assistants hired for this study, who issued and collected questionnaires as well as conducted the preliminary data analysis.

These classifications were made based on 12 questionnaire items. This form of factor analysis first extracts mutually independent factors and then classifies the respondents' motivations based on their 
scores on these factors. The results, obtained through factor analysis, can help us better understand the phenomena and implications of interest, and in doing so, one must always place a study within the context of existing theory and practical applications.

\subsection{Research Subjects and Data Collection}

A total of five temples were used in March 2019 to understand Mazu-themed festival performances across the island. The temples are located in the northern part of Taiwan (temple A), in the central region (temples $\mathrm{B}$ and $\mathrm{C}$ ), and the south (temples D and E). Taking into consideration tax issues and other economic factors, four temples refused to disclose their identity but accepted to take part in the empirical survey. Each temple was accustomed to annually organizing Mazu-themed festivals. Similar to the mass participation ceremony on the deity's important day, on a particular date, the deity makes a procession to affiliated temples several hundred kilometers away, accompanied by a mass of volunteer followers seeking blessings. The most famous example of this practice is for Mazu, dedicated by the Jenn Lann Temple in Dajia, Taichung City. A grand procession to the affiliated Mazu temple, Feng Tian Temple in Singang, Chiayi County, occurs each March of the lunar year with numerous devout believers involved, which also adds to the prosperity of the local economy (Wang 2014a).

In practical terms, religious object commercialization is already a worldwide trend, especially for the enhancement of regional tourism sectors. Therefore, in addition to the preliminary classification of festival visitors as pilgrims and tourists, we also investigated whether the phenomenon of religious object commercialization harms the spirituality of individuals. To seek the answer to the questions, we also surveyed temple B's Mazu-themed festival participants to understand the motivation of the Mazu beliefs of pilgrims and tourists. The survey period was from 23 March to 6 April 2019, during an activity involving approximately 30,000 participants. Cluster sampling was applied to randomly chosen tourists/pilgrims of temples B and C; one researcher conducted the survey at each temple. A total of 330 questionnaires were issued and filled out in person. The survey ruled out respondents who were unwilling to answer and invalid responses, leaving 280 valid interviewees ( $n=280$, approximately $84.8 \%$ ) in this study. Of the sample, as illustrated in Table $1,62.5 \%$ (175) were female, and 37.5\% (105) respondents were male. A total of 40.35\% (113) were 50 years of age or above, $35 \%$ (98) were 30-39 years old, and 20\% (56) were under the age of 29. Regarding the number of visits to the deity-themed festival, most respondents (212) had participated more than two times (75.8\%). Source of information about the festival for $76.1 \%$ (213) of the interviewees was the Internet, social media (e.g., Facebook, Twitter, Line, and WeChat); $17.1 \%$ learned about the event from TV commercials (48). Of the sample, $71.4 \%$ (200) pointed out they were primarily of a folkloric belief, which is a mixture of Buddhism, Confucianism, and Taoism, a widespread traditional faith in the Chinese community.

Table 1. Profile of respondents $(n=280)$.

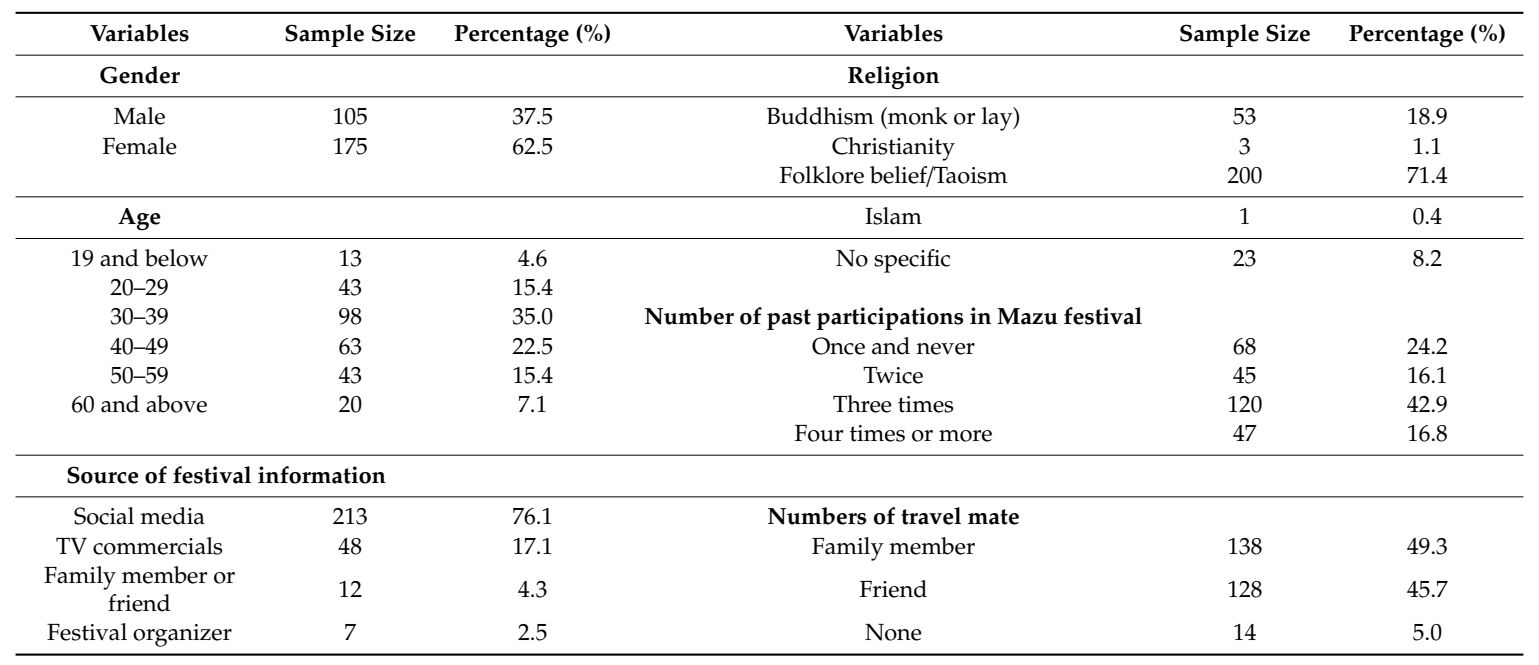




\section{Four Types of Religious Festival Participants}

To effectively classify respondents' motivations to attend a religious event, the researcher also employed a 5 -point Likert scale $(1=$ strongly disagree to $5=$ strongly agree $)$. Factor analysis was used to identify the constructs underlying the 12 posited festival participant motivations from modified questionnaire items originally designed by Crompton and McKay (1997). The questionnaire construction fully considered internal consistencies for each survey item, as well as reliability and validity less than the normal value (Cronbach's alpha value $=0.72$ ). Each item reflected the list of selected topics and was significantly different at $5 \%$. The KMO value was given as 0.83 , meaning that each item could be validly analyzed (Hemmati et al. 2018; Akhoondnejad 2016). Table 2 illustrates the factors influencing the participants of Mazu-themed activities, and the corresponding motivations can be divided into four main types according to the festival participants' motivations: leisure travelers, devout believers, culture enthusiasts, and religious pragmatists.

Table 2. The motivations of religious activity participant-factor analysis result.

\begin{tabular}{|c|c|c|c|c|}
\hline Self-Description & $\begin{array}{l}\text { Leisure } \\
\text { Traveler }\end{array}$ & $\begin{array}{l}\text { Devout } \\
\text { Believer }\end{array}$ & $\begin{array}{l}\text { Cultural } \\
\text { Enthusiast }\end{array}$ & $\begin{array}{l}\text { Religious } \\
\text { Pragmatist }\end{array}$ \\
\hline $\begin{array}{l}\text { I was attracted by the large amount of activity } \\
\text { advertisements }\end{array}$ & 0.819 & 0.149 & 0.259 & 0.083 \\
\hline This activity is like a carnival, I like this atmosphere & 0.723 & 0.099 & 0.343 & 0.046 \\
\hline $\begin{array}{l}\text { I am coming here for this activity, at the same time, I can } \\
\text { visit my friends and relatives }\end{array}$ & 0.849 & 0.143 & 0.114 & 0.092 \\
\hline I am travelling here & 0.771 & 0.043 & 0.035 & 0.134 \\
\hline I am here to salute and worship to Mazu & 0.093 & 0.839 & 0.128 & 0.049 \\
\hline $\begin{array}{l}\text { My family members are all Mazu followers so I } \\
\text { participate in this activity }\end{array}$ & 0.086 & 0.808 & 0.178 & 0.184 \\
\hline Because it is the inherent custom in this place & 0.218 & 0.068 & 0.696 & 0.038 \\
\hline The temple is filled with a sense of history & 0.252 & 0.093 & 0.641 & 0.102 \\
\hline $\begin{array}{l}\text { I believe Mazu will make me and my family happy and } \\
\text { joy if I join the ceremony }\end{array}$ & 0.221 & 0.292 & 0.282 & 0.537 \\
\hline $\begin{array}{l}\text { The temple's ancillary products (e.g., deity dolls, clothes, } \\
\text { hats, amulets) are distinctive }\end{array}$ & 0.252 & 0.041 & 0.388 & 0.613 \\
\hline I always attend this activity; it is so much fun & 0.167 & 0.169 & 0.204 & 0.360 \\
\hline I am coming for fulfill the promise of Mazu blessings & 0.211 & 0.033 & 0.386 & 0.113 \\
\hline Total respondents $(n=280)$ & 70 & 68 & 70 & 72 \\
\hline
\end{tabular}

As seen in Table 2, the factor analysis results revealed that each factor number over 0.5 indicates that the interviewees widely recognized the item. The number of respondents for each type was almost equal. Hence, we classified four basic types of motivation as follows: Leisure travelers, devout believers, cultural enthusiasts, and religious pragmatists.

The leisure traveler accounted for most of the factors. The purpose of such participants consists of having fun travel experiences. They participate in religious activities for leisure and entertainment. Leisure travelers prefer a lively atmosphere, such as the carnival celebrations in Rio de Janeiro, Brazil. In other words, the term tourist for a leisure traveler is much more common than the term pilgrim. Conversely, other participants and family members strongly put their faith in the Mazu belief. Devout believers are active participants attracted by the temple's external promotions. They are undoubtedly the typical pilgrims.

The original intentions of the remaining two types of participants, cultural enthusiasts and religious pragmatists, are difficult to classify as "tourist" or "pilgrim" intentions. Cultural enthusiasts are commonly historian types, passionate about gaining more historical and cultural knowledge; compared to other types of participants, cultural enthusiasts are more interested in the origin and 
knowledge of local historical religions and customs. In Taiwan, famous temples play a central role in local folkloric beliefs. Therefore, they are also full of history and cultural heritage that motivates the participation of cultural enthusiasts. The starting point of cultural enthusiasts, however, is not necessarily on a religious level. In addition, despite the common perception of temple visitors being "belief followers," religious pragmatists tend to recognize that participation in religious activities benefits them in terms of attending Mazu ceremonies and buying associated products (e.g., dolls, clothes, hats, and amulets) as tools to help them realize their wishes. Apparently, their motivation is to meet personal spiritual and material conditions. Furthermore, commercial advertisements influence leisure travelers and religious pragmatists to a higher degree. The survey results indicate that participants were significantly attracted by social network and TV advertising from deity-themed festivals held by a Taoist temple in Taiwan (93.2\% of respondents). Moreover, this article successfully classified the four types of religious festival participants between the tourist and pilgrim dimensions in Taiwan. The classification of participants' motivations also explains the current Mazu-themed activity in the festival and takes into account tourism activities related to religious beliefs and cultural characteristics, thus attracting participants with diverse motivations.

\section{Implications}

We successfully classified the four basic typologies of the motivations of Mazu festival participants and strengthened the marketing classification perspective in the case of annual temple festival participants. Several key points of this research are discussed below.

For the case of leisure-oriented visitors, Swatos (2006) provided an unprecedented perspective on "pilgrimage for eminent persons," and Norman (2011) extended this idea to explore phenomena such as sincere worship and praying to God. In other words, no matter "whom" (the object receiving worship), the object only needs to meet visitors' spiritual needs (e.g., family affections, friendship, love, or happiness) and can be "created" or "shaped." Similarly, the event may also be invented or emphasize historical legendary narratives.

Next, many visitors learned about the Mazu festival from social media and TV promotions. Regarding doubts about "entertaining" religious activities, such as those promoted by for-profit organizations, many temples are seemingly profit oriented due to the high level of competition in Taiwan, which also urges them to actively promote themselves via TV advertising, online communities, ritual narratives, and even ad placements and marketing. Tourism with a cultural theme has become a good entry point for the temple studied in this research. This approach also helps the temple meet the leisure or spiritual needs of worshipers or travelers, as well as to stimulate local economic and tourism development to achieve a mutually beneficial effect.

Third, our factor analysis addresses four types of religious festival participants according to the passage relating to the respondents' motivations. Some travelers who joined the group ceremony where they were motivated by a desire to participate in a public ceremony or activity. Conversely, some visitors were driven more by religious pursuits than by their egoistic needs. In this study, the four types of participants coexist in the religious event. Regarding the differentiation between tourists and pilgrims, despite the small survey sample, the researcher managed to make a preliminary classification of those participants who could implement more precisely targeted sales for future festival marketing events.

\section{Conclusions}

In this study, the researcher performed an exploratory case study of folklore belief temples in Taiwan by studying attendants at the Mazu-themed festival in April 2019. The survey uncovered respondents' motivations for participation. These motivations were classified into four types based on the classification developed by Crompton and McKay (1997): Leisure travelers, cultural enthusiasts, religious pragmatists, and devout believers. This classification can serve as a valuable reference for subsequent studies. 
Communities can open themselves to the phenomenon of secularization and, at the same time, maintain the original intention of the religious doctrine. Furthermore, the survey results show that the influence of the Internet was strongly significant for the two sampled festival marketing activities in 2019. Such marketing strategies are particularly attractive for the young generation and may help address some issues to meet the needs of religious festival participants. Additionally, this empirical study features a quantitative method because of time and cost limitations. Qualitative analysis can also be considered in future research to draw more comprehensive results and conclusions.

The cross-sectional data used for this study may have limited the findings in the sense that if the survey were administered at other times or other locations, the findings may be different. Hence it is proposed future researchers try to avoid this by engaging in a more comprehensive or longitudinal survey. We also suggest that future researchers should examine and segment different religions and locations to extend this preliminary classification, particularly new religious groups founded after World War II, for participants of various activities (e.g., worship, spiritual practices, and festivals). Further studies on other locations are needed, and much work is still required to analyze and empirically test these new ideas.

Author Contributions: All authors contributed equally to this work. All authors wrote, reviewed, and commented on the manuscript. All authors have read and approved the final manuscript.

Funding: This research was funded by Talent Introduction Project of Guangdong University of Petrochemical Technology, "Research on Marketing Planning and Practice of Cultural Theme Tourism Industry Circle".

Conflicts of Interest: The authors declare no conflict of interest.

\section{References}

Akhoondnejad, Arman. 2016. Tourist loyalty to a local cultural event: The case of Turkmen handicrafts festival. Tourism Management 52: 468-477. [CrossRef]

Bakas, Fiona Eva, Nancy Duxbury, and Tiago Vinagre de Castro. 2019. Creative tourism: Catalyzing artisan entrepreneur networks in rural Portugal. International Journal of Entrepreneurial Behavior \& Research 25: 731-52. [CrossRef]

Balbo, Andrea L., Erik Gómez-Baggethun, Matthieu Salpeteur, Arnald Puy, Stefano Biagetti, and Jürgen Scheffran. 2016. Resilience of small-scale societies: A view from drylands. Ecology and Society 21: 53. [CrossRef]

Berg, Per Olof, and Guje Sevón. 2014. Food-branding places-A sensory perspective. Place Branding and Public Diplomacy 10: 289-304. [CrossRef]

Bhatnagar, Navneet, and Arun Kumar Gopalaswamy. 2017. The role of a firm's innovation competence on customer adoption of service innovation. Management Research Review 40: 378-409. [CrossRef]

Bixby, Brian. 2006. Consuming simple gifts: Shakers, visitors, goods. In The Business of Tourism: Place, Faith, and History. Edited by Philip Scranton and Janet F. Davidson. Philadelphia: University of Pennsylvania Press, pp. 85-108, 259-64.

Boivin, Maryse, and Georges A. Tanguay. 2019. Analysis of the determinants of urban tourism attractiveness: The case of Québec City and Bordeaux. Journal of Destination Marketing \& Management 11: 67-79.

Bowdin, Glenn, Johnny Allen, William O'Toole, Rob Harris, and Ian McDonnell. 2006. Events Management, 2nd ed. Oxford: Butterworth-Heinemann.

Brown, Graham. 2007. Sponsor hospitality at the Olympic Games: An analysis of the implications for tourism. International Journal of Tourism Research 9: 315-27. [CrossRef]

Brown, Graham, Andrew Smith, and Guy Assaker. 2016. Revisiting the host city: An empirical examination of sport involvement, place attachment, event satisfaction and spectator intentions at the London Olympics. Tourism Management 55: 160-72. [CrossRef]

Chang, Wen-Chun. 2009. Religious attendance and subjective well-being in an Eastern-culture country: Empirical evidence from Taiwan. Marburg Journal of Religion 14: 1-30.

Chang, Horng-Jinh, Kuo-Yan Wang, and Shean-Yuh Lin. 2012. When backpacker meets religious pilgrim house: Interpretation of oriental folk belief. Journal for the Study of Religions and Ideologies 11: 76-92. Available online: http://www.jsri.ro/ojs/index.php/jsri/article/viewFile/614/545 (accessed on 2 January 2020). 
Chen, Wei-Chih. 2016. Leisure participation, job stress, and life satisfaction: Moderation analysis of two models. Social Behavior and Personality: An International Journal 44: 579-88. [CrossRef]

Cohen, Erik. 1992. Pilgrimage and tourism: Convergence and divergence. In Sacred Journeys: The Anthropology of Pilgrimage. Edited by Alan Morinis. Westport: Greenwood Press, pp. 47-61.

Collins-Kreiner, Noga. 2010. The geography of pilgrimage and tourism: Transformations and implications for applied geography. Applied Geography 30: 153-64. [CrossRef]

Collins-Kreiner, Noga. 2018. Pilgrimage-tourism: Common themes in different religions. International Journal of Religious Tourism and Pilgrimage 6: 8-17.

Crompton, John. L., and Stacey L. McKay. 1997. Motives of visitors attending festival events. Annals of Tourism Research 24: 425-39. [CrossRef]

Dewar, Keith, Denny Meyer, and Wen Mei Li. 2001. Harbin, lanterns of ice, sculptures of snow. Tourism Management 22: 523-32. [CrossRef]

Dhakal, Basanta, Azaya Bikram Sthapit, and Shankar Prasad Khanal. 2017. Factor analysis of local residents' perceptions towards social impact of tourism in Nepal. International Journal of Statistics and Applied Mathematics 2: 1-8.

Durán-Sánchez, Amador, José Álvarez-García, Maria De la Cruz Río-Rama, and Cristiana Oliveira. 2018. Religious tourism and pilgrimage: Bibliometric overview. Religions 9: 249. [CrossRef]

Duxbury, Nancy, Fiona Eva Bakas, and Cláudia Pato de Carvalho. 2019. Why is research-practice collaboration so challenging to achieve? A creative tourism experiment. Tourism Geographies, 1-26. [CrossRef]

Getz, Donald. 2010. The nature and scope of festival studies. International Journal of Event Management Research 5: 1-47.

Getz, Donald, and Stephen J. Page. 2016. Progress and prospects for event tourism research. Tourism Management 52: 593-631. [CrossRef]

Grappi, Silvia, and Fabrizio Montanari. 2011. The role of social identification and hedonism in affecting tourist re-patronizing behaviours: The case of an Italian festival. Tourism Management 32: 1128-40. [CrossRef]

Guo, Yingzhi, Samuel Seongseop Kim, Dallen J. Timothy, and Kuo-Ching Wang. 2006. Tourism and reconciliation between Mainland China and Taiwan. Tourism Management 27: 997-1005. [CrossRef]

Hemmati, Farhad, Fatemeh Dabbaghi, and Ghahraman Mahmoudi. 2018. Iran's need for medical tourism development. Journal of Research in Medical and Dental Science 6: 269-73.

Iriobe, Ofunre, and Elizabeth Abiola-Oke. 2019. Moderating effect of the use of eWOM on subjective norms, behavioural control and religious tourist revisit intention. International Journal of Religious Tourism and Pilgrimage 7: 38-47. [CrossRef]

Kawano, Satsuki. 2005. Ritual Practice in Modern Japan: Ordering Place, People, and Action. Honolulu: University of Hawai'i Press.

Kim, Hyunjung. 2005. Structure and significance of the Japanese urban festival: Diachronic and synchronic analyses of structure of the annual festival of Hitachinokuni Sosha shrine in Ishioka City. Journal of Korean Society for Cultural Anthropology 38: 45-81.

Kim, Hyounggon, Marcos C. Borges, and Jinhyong Chon. 2006. Impacts of environmental values on tourism motivation: The case of FICA, Brazil. Tourism Management 27: 957-67. [CrossRef]

Kim, Bona, Seongseop Sam Kim, and Brian King. 2016. The sacred and the profane: Identifying pilgrim traveler value orientations using means-end theory. Tourism Management 56: 142-55. [CrossRef]

Kitagawa, Joseph M. 1988. Some Remarks on Shintō. History of Religions 27: 227-45. [CrossRef]

Kluver, Randolph, and Pauline Hope Cheong. 2007. Technological Modernization, the Internet, and Religion in Singapore. Journal of Computer-Mediated Communication 12: 1122-42. [CrossRef]

Lee, Jung Wan, and Michael Kwag. 2019. Structural equation modelling with second-order confirmatory factor analysis: Critical factors influencing consumer behavior in medical tourism. In Quantitative Tourism Research in Asia. Singapore: Springer, pp. 223-43.

Lee, Choong-Ki, Yong-Ki Lee, and Bruce E. Wicks. 2004. Segmentation of festival motivation by nationality and satisfaction. Tourism Management 25: 61-70. [CrossRef]

Li, Yan-Ning, and Emma H. Wood. 2016. Music festival motivation in China: Free the mind. Leisure Studies 35: 332-51. [CrossRef]

Liao, Chu-Chu, Ying-Xing Lin, and Huey-Hong Hsieh. 2019. Satisfaction of indigenous tourism from residents' perspective: A case study in Nantou county, Taiwan. Sustainability 11: 276. [CrossRef] 
Liutikas, Darius. 2017. The manifestation of values and identity in travelling: The social engagement of pilgrimage. Tourism Management Perspectives 24: 217-24. [CrossRef]

Lyu, Seong Ok, and Hoon Lee. 2016. Latent demand for recreation participation and leisure constraints negotiation process: Evidence from Korean people with disabilities. Journal of Leisure Research 48: 431-49. [CrossRef]

Mariani, Marcello M., and Luisa Giorgio. 2017. The "Pink Night" festival revisited: Meta-events and the role of destination partnerships in staging event tourism. Annals of Tourism Research 62: 89-109. [CrossRef]

Matoga, Łukasz, and Aneta Pawłowska. 2018. Off-the-beaten-track tourism: A new trend in the tourism development in historical European cities. A case study of the city of Krakow, Poland. Current Issues in Tourism 21: 1644-69. [CrossRef]

Moore, Mark. H. 2000. Managing for value: Organizational strategy in for-profit, nonprofit, and governmental organizations. Nonprofit and Voluntary Sector Quarterly 29: 183-204. [CrossRef]

Moufahim, Mona, and Maria Lichrou. 2019. Pilgrimage, consumption and rituals: Spiritual authenticity in a Shia Muslim pilgrimage. Tourism Management 70: 322-32. [CrossRef]

Mwebaza, Susan, Julius Jjuuko, and Provia Kese. 2018. Religious Tourism and Pilgrimage: Conflicts and Challenges. A case of the Namugongo Martyrs Shrines in Uganda. Turystyka Kulturowa 7: 117-31.

Norman, Alex. 2011. Celebrity push, celebrity pull: Understanding the role of the notable person in pilgrimage. Australian Religion Studies Review 24: 317-41. [CrossRef]

Onwezen, Marleen. 2018. Including context in consumer segmentation: A literature overview shows the what, why, and how. In Methods in Consumer Research. Sawston: Woodhead Publishing, vol. 1, pp. 383-400. [CrossRef]

Özdemir, Bahattin, and Faruk Seyitoğlu. 2017. A conceptual study of gastronomical quests of tourists: Authenticity or safety and comfort? Tourism Management Perspectives 23: 1-7. [CrossRef]

Prentice, Richard, and Vivien Andersen. 2003. Festival as creative destination. Annals of Tourism Research 30: 7-30. [CrossRef]

Rowley, Jennifer, and Catrin Williams. 2008. The impact of brand sponsorship of music festivals. Marketing Intelligence E Planning 26: 781-92.

Ruiz, Elena Cruz, Elena Ruiz Romero De la Cruz, and Francisco J. Calderón Vázquez. 2019. Sustainable Tourism and Residents' Perception towards the Brand: The Case of Malaga Spain). Sustainability 11: 292. [CrossRef]

Saayman, Melville, and Andrea Saayman. 2006. Does the location of arts festivals matter for the economic impact? Papers in Regional Science 85: 569-84. [CrossRef]

Shimazono, Susumu. 1998. The commercialization of the sacred: The structural evolution of religious communities in Japan. Social Science Japan Journal 1: 181-98. [CrossRef]

Shiomura, Takashi. 2009. Cultural polarization in increasingly nonlocal societies. Sociological Theory and Methods 24: 95-108.

Shuo, Yeh Sam Shih, Chris Ryan, and GeMaggie Liu. 2009. Taoism, temples and tourists: The case of Mazu pilgrimage tourism. Tourism Management 30: 581-88. [CrossRef]

Swatos, William H. 2006. On the Road to Being There: Studies in Pilgrimage and Tourism in Late Modernity. Leiden: Brill Academic Pub, vol. 12.

Takele, Yezihalemâ Sisayâ. 2019. International Tourism demand and determinant factor analysis in Ethiopia. International Journal of Systems and Society IJSS) 6: 27-51. [CrossRef]

Tanaka, Atsushi. 2014. Proposal of alleviative method of community analysis with overlapping nodes. IEEE Fourth International Conference on Big Data and Cloud Computing, 371-77. [CrossRef]

Timoshenko, Artem, and John R. Hauser. 2019. Identifying customer needs from user-generated content. Marketing Science 38: 1-20. [CrossRef]

Tomochi, Masaki. 2010. A model of a nested small-world network. Sociological Theory and Methods 25: 19-29.

Tsao, Karen. 2014. Mazu Cultural Festival and City Sustainable Development in Taichung. Available online: http: //www.agenda21culture.net/sites/default/files/files/good_practices/taichung-eng.pdf (accessed on 1 August 2020).

United Nations Educational, Scientific and Culture Organization (UNESCO), and The Mazu Belief and Customs. 2009. Intangible Heritage Lists of 2009. Available online: http://ich.unesco.org/en/RL/mazu-belief-andcustoms-00227 (accessed on 5 August 2020).

Viljoen, Armand, Martinette Kruger, and Melville Saayman. 2017. The 3-S typology of South African culinary festival visitors. International Journal of Contemporary Hospitality Management 29: 1560-79. [CrossRef] 
Wang, Kuo-Yan. 2014a. Religious Service development of folk religion temples in Taiwan: A comprehensive perspective. Review of Integrative Business and Economics Research 4: 49-54.

Wang, Kuo-Yan. 2014b. When a Taoist temple serves as a seller and believer becomes a buyer. Review of Religious Research 56: 341-42. [CrossRef]

Wang, Kuo-Yan. 2019. Balancing environmental protection and folk belief: Surveying the attitudes of local worshipers. DEStech Transactions on Environment, Energy and Earth Sciences PEEMS). [CrossRef]

Wang, Yue, Daniel Y. Mo, and Mitchell M. Tseng. 2018. Mapping customer needs to design parameters in the front end of product design by applying deep learning. CIRP Annals 67: 145-48. [CrossRef]

Wong, Maggie Hiufu. 2013. Mazu Mania: Free Food, Great Parties. Wait, This Is a Religious Festival? CNN Travel, April 12. Available online: http://travel.cnn.com/taiwan-mazu-religious-festival-pilgrimage226351/ (accessed on 5 August 2020).

Woosnam, Kyle M., Kayode D. Aleshinloye, Manuel Alecto Ribeiro, Dimitrios Stylidis, Jingxian Jiang, and Emrullah Erul. 2018. Social determinants of place attachment at a World Heritage Site. Tourism Management 67: 139-46. [CrossRef]

Ying, Tianyu, and Jun Wen. 2019. Exploring the male Chinese tourists' motivation for commercial sex when travelling overseas: Scale construction and validation. Tourism Management 70: 479-90. [CrossRef]

Zaidman, Nurit. 2003. Commercialization of religious objects: A comparison between traditional and new age religions. Social Compass 50: 345-60. [CrossRef]

Zhang, Carol Xiaoyue, Lawrence Hoc Nang Fong, Shi Na Li, and Tuan Phong Ly. 2019. National identity and cultural festivals in postcolonial destinations. Tourism Management 73: 94-104. [CrossRef]

(C) 2020 by the authors. Licensee MDPI, Basel, Switzerland. This article is an open access article distributed under the terms and conditions of the Creative Commons Attribution (CC BY) license (http://creativecommons.org/licenses/by/4.0/). 